直角に交っているので，関節窩に向け，肩甲棘に直角に 射入する).

フィルムは検側肩上, 中心X線に直角に位置する。局 甲三角像を逃さぬよう, 頸の方へ充分押さえ込み, 焦点 距離を大きくとる.

II. 立位法

椅子の背に腹側を着けてあたれかかり，外科用イメー ジを用い，中心X線の射入は腹卧位法と同じくする.

腹卧位法では肩甲骨が外転位や外旋位になりやすいの で注意し，立位法では上記の点は防げるが，体位が不安 定である.

晒骨X線像ならびに生体健康 X線像とそのおのおのの 線描を供覧し，読影の一助とした。

肩甲棘骨折症例も供覧した。

\section{6. 耳小骨撮影法の検討（第一報）}

虎の門病院 放射線科

菊地 貞吉・片 倉 剛・菅野由起夫 関東学災病院 放射線科

鍵田 政雄・小川 敬寿・久松 克次

（1）耳小骨の撮影仙可能かどうか.

(2) 可能の場合, どの程度まで耳小骨形状を写出せる 加.

（3）従来の耳系撮影法において，耳小骨の位置，およ び障害陰影などの関係はどうか。

以上から単純撮影においてもっとも有利と思われるも のについて検討を加えた。

\section{〔実験方法]}

耳鼻科用乾燥骨の耳小骨に印を付㵊影し，また毫写 を併せ行なった，その結果ギラン氏法方向がX線透過性 から有利と考え体位について検討を加えた。

[ギラン氏法の検討]

前記同様の奏験方法で仰角 $90^{\circ} 80^{\circ} 70^{\circ}$ 傾斜角 $85^{\circ} 80^{\circ}$ $75^{\circ}$ の組み合について行なった結果，仰角，傾斜角各 $80^{\circ}$ においてもっともよい結果を得た。

さらに拉大立体撮影を併用し，実写を行なった。拡大 1.5倍，立体中心線 (左)眼窩 (右)涙点の中心，乙の場合， 人字縫合および水平半規管の先端に耳小骨が写し出され る.

\section{[結論]}

（1）今回検討した各撮影法とも障害陰影により耳小骨 全形状の描出は困難であった。

（2）本法は外耳，中耳の耳小骨から内耳への関係が連 続して観察出来る.

（3）読影上拡大立体撮影を侀用した方法が有効であっ
$た$.

（4）患側のみでなく，両側の対称撮影が必要と思われ る.

以上単純撮影では障害陰影を除くには限界があるので, 断層，ステレオ断圏，ポリトームなどを使用したものに ついて，検討を続けたい。

\section{7. 頸推推間孔撮影法}

豊橋市民病院 放射線科
遠藤 重男・鈴木 経二
宮下 金人・朝倉 正己

頸推推間孔撮影には種々の方法が行なわれているが常 に明瞭なX線写真を得ることは個人差，撮影体位の違い などにより必ずしも容易ではなままた治愈経過を確実に 把握するためには同一角度，同一体位で撮影されたX線 写真が必要である.

私共はオッペンハイマー氏撮影法を応用しとの方法に 改良を加えて撮影法の検討を行なった．推間孔を明暸に 撮影するために重要なX線入射角度の決定には88例の生 体頸部の回転横断撮影を行なし得られた写真から正中線 に対する推間孔の角度を計測した。そ結果88例中， 74 例すなわち $85.2 \%$ 特 $50^{\circ} \pm 2^{\circ}$ の範囲内であった。 との計 測結果を基㵊影台を製作した。 元来オッペンハイマー 氏撮影法は腹卧位での撮影であるが，私共の経験から立 位での撮影が患者の苦痛がすくなく撮影体位が得られる ととが判明した。

過去 2 年 6 カ月間に私共の撮影法で推間孔を撮影した 157例中全推間孔を明瞭に撮影できたすのは128例であっ た．全推間孔を明瞭にできない場合は個人差でX線入射 角度が $50^{\circ}$ よりずれて居る場合が多くこのような時には 頸部の回転横断撮影を行ない角度を計測し，さらに得ら れた入射角度で撮影すれば良い。

以上の結果比較的容易に目的を果すととが判ったので 私共が実際に行なっている撮影の方法と結果を展示供覧 した。

\section{8. 手根骨㵊影における一考案 \\ 末永式手根骨（豆状骨，有鈎骨，大菱形骨）軸位 撮影法}

町立国民健康保険稲城中央病院，放射線科

末永 昭雄

\section{〔緒言】}

手根骨は不用意に手を地面についた時，あるいは高い ところから落ちて打った時，揄挫時には骨折を来し易い ところである. 手根骨は解剖学的に 8 個の短骨が 4 個ず つ2列にならび近位列は舟状骨，月状骨，三角骨，豆状 
骨遠位列は大菱形骨，小菱形骨，有頭骨，有釣骨である． 普通一般に行なわれている撮影方法には後前位，側位 斜位 ( $45^{\circ}$ 回内, 回外) 外転位とあるが手根骨は 8 個の 骨がたがいに重畳して骨の辺縁が明瞭仪読影できないと きがある，そこで 8 個の骨がそれぞれ分離した状態でな くても 1 個または 2 個でも他の骨之重骨しないで撮影で きる新しい軸位撮影方法を試み良い結果を得ることがで きた，浅学非才の身ではありますが，むし現在まで先輩 諸賢にての方法が行なわれていないならば本法を末永式 手根骨（豆状骨，有鈎骨大菱形骨）軸位撮影法と表現し たい.

従来まで本邦ならびに外国の文献で私の知る軸位撮影

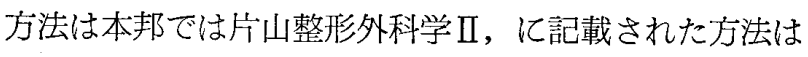
手背をフィルム面汇打き前腕と手のなす角度を直角とし X線を $45^{\circ}$ の方向から照射する方法である. 外国の文献 ではガイノールハルトの方法は前腕を最大背屈にして頭 側に曲げ，X線はフィルム面に対して 25〜30 で第 4 中 手骨の基底部より先端を通す方法である。

今回私の行なった実験方法は手掌をフィルム面に密着 乙前腕と手のなす角度を直角 $\left(90^{\circ}\right)$ 亿固定しX線入射角 度を $20^{\circ} \sim 75^{\circ}$ （X線管球角度 $70^{\circ} \sim 15^{\circ}$ ） まで变化する.

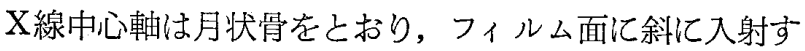
る. との方法化上り豆状骨, 有鈎骨, 大荾形骨が各撮影 角度によりどのような形に現われるか実験を行なった。 （成人男子，成人女子について行なった）

\section{[考察]}

実験により近位列㲹存在する豆状骨と遠位列に存在す る有鈎骨, 大菱形骨の写真上に現われる像はX線入射角 度汇より相異する. 豆状骨はX線入射角度 $50^{\circ} \sim 60^{\circ}$ (水 平面 $0^{\circ}$ より）（X線管球角度 $40 \sim 30^{\circ}$ ）の範围が他の骨 と重復しないで豆のごとく丸く現われる. 有鈎骨はX線

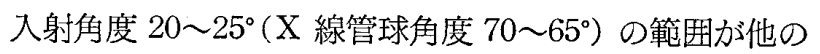
骨と重復しないでもっとも長く現われる. 大菱形骨はX

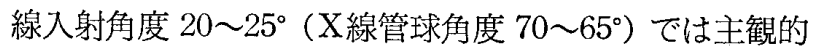
であるが引きのばされた菱形に見え $X$ 線入射角度 30 $40^{\circ}$ (X線管球角度 $60 \sim 50^{\circ}$ ) では引きのばされない菱形 に見える. カルパールトンネルは上記実験範囲の写真像 に現われているが，どの撮影角度が最適であるか私には 不明である，遠位列汇存在する有鈎骨，大菱形骨の撮影 角度はほぼ同じと考えられるが，近位列の豆状骨が豆の 形に現われる撮影角度は有鈎骨, 大菱形骨の撮影角度之 大きな差がある．しかし豆状骨の骨折の有無を読影する とき豆の形に，あるいは棈円形 (ピーナツ状) に現われ た時の, どちらが骨折の診断が容易であるか X線入射角
度 (X線管球角度) を変化させて豆状骨骨折の成人男子 の患者を実際に撮影してみた。

X線入射角度 $55^{\circ}$ (X線管球角度 $35^{\circ}$ ) の豆状骨は骨折 線しか分らないが，X線入射角度 $30^{\circ}$ (X線管球角度 $60^{\circ}$ ) の豆状骨は 2 つの切片に分離していることが分る，ての ことは楕円形(ピーナツツ状)に現われた方が骨折の診断 が容易ではないかと私は思います。このととょり手根骨 (豆状骨, 有鈞骨, 大菱形骨) 軸位撮影角度はX線入射角

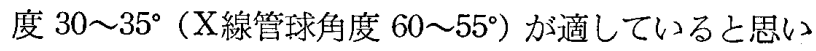
ます。なぜならとの角度は実験のでとく大菱形骨は極端 に引きのばされない菱形に見え，有鈎骨もX線入射角度 25に比較して長さが大差なく豆状骨む楕円形に現われ 骨折の診断が容易であると考えたからであります．豆状 骨の骨折は切片の分離が伴はないとともあると考えられ るので分離状態だけでなく豆状骨の形，ならびに骨折線 を見たいときは，X線入射角度 50 ～60 (X線管球角度 40～ $30^{\circ}$ ) で撮影するのも一方法と考えられる. ての撮影 角度は豆状骨が豆の形に現われる，なお手の受傷程度に より手と前腕のなす角度が直角 $\left(90^{\circ}\right)$ にならないときは この方法を行なうことはできない.

未永式手根骨（豆状骨，有鈎骨，大菱形骨）軸位撮影 法.

体位＝患側の上肢は真直ぐとし前腕と手のなす角度を 直角 $\left(90^{\circ}\right)$ とする. 手掌はフィルム面に密着し健側の手 は撮影台につかまるようにするてのとき体で撮影台を押 すような気持ちにすると患側の手の固定が容易である。

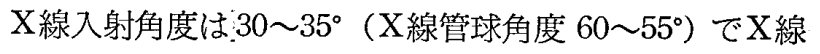
中心軸は月状骨を通り（成人においてフィルム面から約

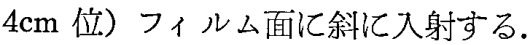

撮影条件(成人) $60 \mathrm{kVp} 200 \mathrm{~mA} 0.3 \mathrm{sec} 80 \mathrm{~cm}$

$$
\begin{aligned}
& \text { ノーンスクリン, さくらニューYタ } \\
& \text { イプ. }
\end{aligned}
$$

\section{9. 肩甲骨側方向撮影法の一考案}

九州厚生年金病院 放射線室

増 野 豊・岡部 - 健吾
田中 高生・岡田 寅彦
吉武 清秀 $\bigcirc$ 堀尾 重治
松尾 春生・田中 誠
八幡製鉄保険館
田島 成幸

〔緒言〕

田島 成幸

現在肩甲骨の側方向撮影汇関して数多くの方法が紹介 されているが，乙れ等の方法を用いて満足すべき結果を 得るととはなかなか容易なととでない。そとでわれわれ 